\title{
Annual Report of Korean Association of External Quality Assessment Service on Histocompatibility Testing (2018)
}

\section{Eun-Suk Kang}

Department of Laboratory Medicine and Genetics, Samsung Medical Center, Sungkyunkwan University School of Medicine, Seoul, Korea

\section{Corresponding author:} Eun-Suk Kang

Department of Laboratory

Medicine and Genetics, Samsung Medical Center, Sungkyunkwan University School of Medicine, 81 Irwon-ro, Gangnam-gu, Seoul 06351, Korea

Tel: $+82-2-3410-2703$

Fax: +82-2-3410-2719

E-mail: eskang@skku.edu

\section{서론}

조직적합성 (histocompatibility)검사는 성공적인 이식 을 위해서는 필수적인 검사이다. 조직적합성항원(human leukocyte antigen, HLA) 또는 주조직복합체(major histocompatibility complex) 형별검사(HLA typing)는 장기 및 조혈모세포 이식 전 최적의 공여자를 선별하고, HLA 교차 시험(HLA crossmatching) 및 HLA 항체검사(HLA antibody testing)를 통해 부적합 공여자를 배제하고 이식 후 경과를 예 측하는 데 중요한 정보를 제공한다. 일부 특정 HLA형은 질병 연관성이 높아 특정 질병을 진단하는 것에 이용된다. 특히 국 내에서 이식을 위한 타인 공여자의 매칭은 질병관리본부 장기 이식관리센타(Korean Network for Organ Sharing)의 중앙 화된 정보시스템을 통해 이루어지고 있으며 이때 여러 다른기 관에서 시행후 입력한 검사결과를 바탕으로 선정하게 된다. 그
러므로 기관 간 HLA검사의 표준화와 호환성은 매우 중요하 다.

국내에서는 1993 년 설문조사를 통해 18 개 기관이 HLA검사 를 시행하고 있음을 확인한 이후 지속적으로 검사시행기관이 증가되어 왔다[1]. 국내 외부정도관리프로그램은 Park 등[2] 이 국내 프로그램을 개발하고자 1996년부터 1998년에 걸쳐 국가연구비 기반의 시범사업으로 시작하였으며, 2000년도부 터는 대한진단검사의학회 정도관리분과 사업의 일환으로 본 격적으로 진행되어 2017년도까지 지속되었다. 대한임상검사 정도관리협회는 2017 년 국가 질 관리료 산정에 따른 기관평가 가 도입됨에 발맞추어 차세대신빙도조사사업의 일환으로 차 세대전산시스템의 도입과 더불어 분야 및 항목의 확대를 추진 하여 왔으며 2018년 조직적합성검사 외부정도관리프로그램을 도입하였다. 따라서 18년간 지속해온 대한진단검사의학회 정 도관리분과의 조직적합성 외부정도관리프로그램은 중단되고 
현재의 프로그램으로 대체되었다.

조직적합성검사프로그램은 진단면역학 대분류 내 중분류 에 해당하며 소분류에 기존의 외부정도관리프로그램과 동일 하게 조직적합성 형별검사(HLA typing), 특수조직적합성 형 별검사(HLA-B27 typing), 조직적합성 교차시험검사(HLA crossmatching), 그리고 조직적합성 항체검사(HLA antibody testing) 항목을 포함하며 연 2회에 걸쳐 진행되었다.

이에 저자는 2018년 대한임상검사정도관리협회에서 시행된 첫 조직적합성검사 신빙도조사 결과와 내용을 보고하고자 한 다.

\section{재료 및 방법}

\section{1. 조사항목}

조직적합성검사프로그램은 연 2회에 걸쳐 HLA 형별검 사, HLA-B27 검사, HLA 교차시험, 그리고 HLA 항체 선별 (screening)과 동정(identification) 검사 총 5 개 항목에 대해 시행되었다. 신선한 세포로 배송되어야 하는 특성상 24-72시 간에 검체가 전달되도록 신속 예약배송시스템을 활용하였고, 실온상태에서 세포 신선도를 보증하기 위하여 외부 기온이 높 지 않은 4월 첫째 주와 10 월 둘째 주 월요일에 발송하였다.

\section{2. 외부신빙도조사용 정도관리물질}

검체의 제조는 자가제조물질 개발 용역연구를 맡은 삼성서 울병원에서 수행하였다. 검체 제조를 위한 혈액을 확보하기 위 하여 연구윤리위원회(Institutional Review Board)의 심의 를 득하였으며 공지문을 통해 자원자를 모집하였다. 자원자는 혈액공여자 선별기준에 따라 적합성을 확인하였다. 자가제조 된 물질은 분주 및 라벨링을 마친 후 대한임상검사정도관리협 회로 즉시 운반되어 포장된 후 각 참여기관으로 당일 발송되 었다. 국내 특급우편을 이용하여 혈청은 냉장, 세포는 실온상 태에서 배송되었으며 발송 후 24-48시간 내에 검사실에 도착 될 수 있도록 하였다. 제주도의 경우에는 항공우편을 이용하여 72시간 내에 도착될 수 있도록 하였다.

\section{1) HLA 형별검사 및 HLA-B27형 검사용 전혈 제조}

자원자들을 대상으로 미리 HLA 형별검사를 시행하여 교차시험에서도 활용할 수 있는 HLA 형과 HLA-B27 양 성 검체를 확보하였다. 발송 당일 선별한 자원자들로부터 ethylenediaminetetraacetic acid 전혈을 채집한 후 시험관당 $1 \mathrm{~mL}$ 씩 즉시 분주하였다. 회차당 각각 2 개씩의 검체를 제조하 였다.

\section{2) HLA 교차시험용 단핵구 부유액 제조}

교차시험에서 적절한 반응을 보이는 HLA 형을 가진 자원자 로부터 발송 당일 혈액분반술을 통해 필요한 수의 단핵구를 채 집하였다. 채집 즉시 $0.5-1 \times 10^{7} / \mathrm{mL}$ 의 농도가 되도록 자가혈 장으로 희석한 후 시험관당 $1 \mathrm{~mL}$ 씩 분주하였다. 회차당 각각 2 개씩의 검체를 제조하였다.

\section{3) HLA 교차시험 및 항체동정용 혈청 제조}

신장이식 대기 중 단일항원형 비드동정(single antigen bead identification)검사를 통해 항원 특이성이 밝혀진 환자 로부터 서면동의서를 획득한 후 약 $100 \mathrm{~mL}$ 의 전혈을 채집하 였다. 채집 전 담당 임상의로부터 환자 상태에 대한 자문을 구 하였으며 상태에 따라 한번에 $100 \mathrm{~mL}$ 또는 2차에 나누어 총 $100 \mathrm{~mL}$ 를 헌혈실에서 채집하였다. 약 2 시간 방치하여 충분 한 혈액응고가 진행된 후 $3,000 \mathrm{rpm}$ 에서 15 분간 원심분리 후 혈청을 회수하였다. 혈청은 $0.2 \mu \mathrm{m}$ 필터를 사용하여 처리 후 $-70^{\circ} \mathrm{C}$ 에 냉동보관하였다. 발송 당일 해동하여 다시 한번 원심 분리 후 상층액을 시험관당 약 $500 \mathrm{~L}$ 씩 분주하였다. 회차당 각 각 2 개씩의 검체를 제조하였다.

\section{3. 결과 판정 및 분석}

결과는 차세대신빙도사업 홈페이지에 입력하도록 하였고, 입력기간은 발송 후 2 주에 종료하였다. 이후 입력결과에 대 한 데이터 오류를 검증한 후 통계분석을 시행하였다. 모든 항 목은 정성검사에 준하여 판정하였으며 기대결과(intended response)는 신뢰할 만한 정답이 있는 경우와 그렇지 않은 경 우에는 보고한 기관에서 $80 \%$ 이상의 일치를 보이는 결과로

Table 1. Participating laboratories and response rates of the histocompatibility program

\begin{tabular}{lcr}
\hline Test items & 1st & 2nd \\
\hline HLA typing & & \\
Low resolution & $100(37 / 37)$ & $100(37 / 37)$ \\
Low and high resolution & $100(65 / 65)$ & $100(67 / 67)$ \\
HLA crossmatching & & \\
T cell & $100(48 / 48)$ & $98(47 / 48)$ \\
B cell & $100(31 / 31)$ & $88(29 / 33)$ \\
HLA antibody & & \\
Screening & $100(20 / 20)$ & $95(19 / 20)$ \\
Identification & $100(22 / 22)$ & $100(22 / 22)$ \\
HLA-B27 typing & $100(56 / 56)$ & $100(60 / 60)$ \\
\hline
\end{tabular}

Values are presented as \% (number of participating laboratories). Abbreviation: HLA, human leukocyte antigen. 
하였다. 단, HLA 교차시험의 경우 민감도가 다른 두 가지 이 상의 검사법을 반드시 시행하도록 권고하고 있는 바 민감도가 높은 검사에서 $80 \%$ 이상의 일치를 보이지 않는 경우 하위검 사의 결과는 Code 505 로 기술하고 판정 제외하였다. HLA 교 차시험의 반정량 결과와 HLA 항체 항원성 동정 결과는 별도 로 판정하지 않았다.

\section{결과}

\section{1. 신빙도조사사업 참여기관 현황}

각 항목별로 2018년도 신빙도조사에 참여한 기관 수 및 회 신율은 1 차에서는 $100 \%$ 의 회신율을 보였으나 2 차에서는 $\mathrm{HLA}$ 교차시험에서 $\mathrm{T}$ 세포와 $\mathrm{B}$ 세포 각각 1 기관과 4 기관 그 리고 HLA 항체 선별검사에서 1기관이 회신하지 않아 $98 \%$, $88 \%$ 그리고 $95 \%$ 의 회신율을 보였으며 그 외 항목에서는

Table 2. Methods of HLA typing for different loci

\begin{tabular}{|c|c|c|c|c|c|c|}
\hline \multirow[b]{2}{*}{ Resolution/methods/manufacturers } & \multicolumn{3}{|c|}{1 st } & \multicolumn{3}{|c|}{ 2nd } \\
\hline & $\begin{array}{c}\text { HLA-A, } \\
-B,-D R B 1\end{array}$ & HLA-C & HLA-DQ & $\begin{array}{c}\text { HLA-A, } \\
\text {-B, -DRB1 }\end{array}$ & HLA-C & HLA-DQ \\
\hline Low resolution generic type & 65 & 39 & 29 & 67 & 42 & 34 \\
\hline Sequence-based typing & 13 & 13 & 8 & 14 & 14 & 9 \\
\hline Biowithus Inc. & 7 & 7 & 3 & 8 & 8 & 4 \\
\hline GenDx & 5 & 5 & 4 & 5 & 5 & 4 \\
\hline One Lambda & 1 & 1 & 1 & 1 & 1 & 1 \\
\hline Sequence-specific oligonucleotide probe reverse & 26 & 13 & 16 & 29 & 15 & 18 \\
\hline Fujirebio Inc. & 7 & 5 & 2 & 9 & 7 & 2 \\
\hline Immucor Lifecodes & 12 & 5 & 9 & 12 & 5 & 10 \\
\hline One Lambda & 7 & 3 & 5 & 8 & 3 & 6 \\
\hline Sequence-specific primers & 21 & 9 & 3 & 19 & 9 & 4 \\
\hline Biosewoom & 11 & 4 & 2 & 9 & 3 & 2 \\
\hline One Lambda & 10 & 5 & 1 & 10 & 6 & 2 \\
\hline Other methods & 5 & 4 & 2 & 5 & 4 & 3 \\
\hline Biosewoom & 1 & 1 & 2 & 2 & 2 & 1 \\
\hline Biowithus Inc. & 1 & 1 & - & - & - & 1 \\
\hline Others & 3 & 2 & - & 3 & 2 & 1 \\
\hline High resolution allelic type & 28 & 27 & 14 & 29 & 28 & 16 \\
\hline Sequence-based typing & 24 & 24 & 11 & 25 & 25 & 12 \\
\hline Biowithus Inc. & 14 & 14 & 5 & 15 & 15 & 6 \\
\hline GenDx & 8 & 8 & 5 & 8 & 8 & 5 \\
\hline One Lambda & 2 & 2 & 1 & 2 & 2 & 1 \\
\hline Sequence-specific oligonucleotide probe reverse & 1 & - & - & 1 & - & 1 \\
\hline Fujirebio Inc. & 1 & - & - & 1 & - & - \\
\hline Immucor Lifecodes & & - & - & - & - & 1 \\
\hline Other methods & 3 & 3 & 3 & 3 & 3 & 3 \\
\hline Biosewoom & 2 & 2 & 1 & 2 & 2 & 1 \\
\hline Biowithus Inc. & 1 & 1 & 2 & - & - & 1 \\
\hline Others & - & - & - & 1 & 1 & 1 \\
\hline
\end{tabular}

Abbreviation: HLA, human leukocyte antigen.

The instruments were from the following companies: Biowithus Inc. (Seoul, Korea); GenDx (Utrecht, The Netherlands); One Lambda (Canoga Park, CA, USA); Fujirebio Inc. (Tokyo, Japan); Immucor Lifecodes (Stamford, CT, USA); and Biosewoom (Seoul, Korea). 


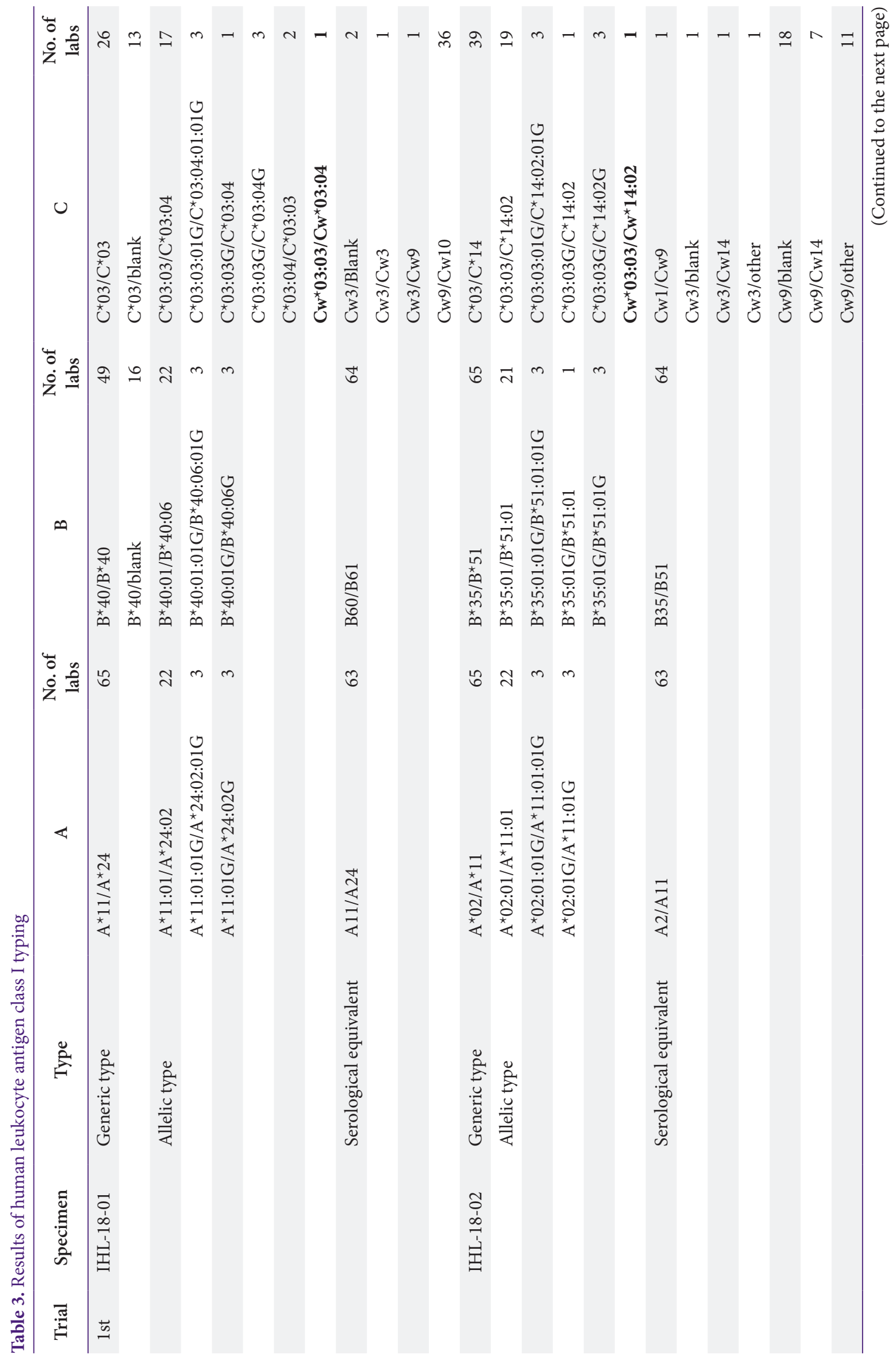




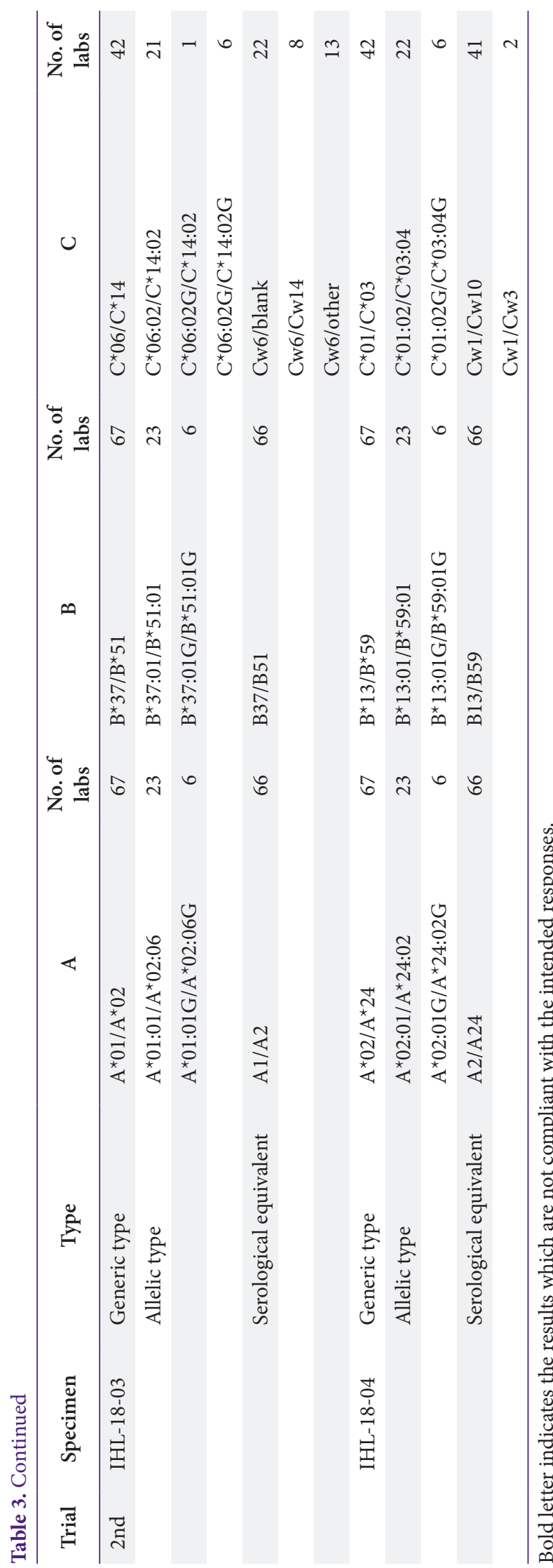

$100 \%$ 였다(Table 1).

\section{2. 조직적합성 형별검사}

참여한 모든 기관이 $\mathrm{DNA}$ 형별검사에 기반한 결과를 보 고하였다. 저해상도 형별검사의 경우 sequence specific oligonucleotide probe reverse (rSSOP)와 sequence specific primers (SSP)가 가장 널리 사용되는 방법이었다. 고해상도 형별검사의 경우에는 sequence-based typing이 대다수를 차 지하였으나 3 기관은 그 외 방법을 사용하는 것으로 보고하였 고 한 기관은 $\mathrm{rSSOP}$ 법으로 고해상도검사를 시행한 것으로 보고하였다(Table 2). 2018년도 발송된 총 4개의 물질에 대 한 class I과 class II에 대한 보고 결과는 Table 3 및 Table 4 와 같다. HLA-A와 HLA-B에 대한 저해상도와 고해상도 결 과에 대한 정답률은 모두 $100 \%$ (264/264, 114/114)였다. 그 러나 HLA-C에 대한 정답률은 저해상도 결과에서는 $100 \%$ (162/162)였으나 고해상도 결과에 대해서는 98\% (108/110) 를 보였는데, 형별 결과는 기대결과에 부합하였으나 표기법상 유전자좌를 혈청형과 같은 $C W$ 로 표기하여 잘못된 용어표기법 (nomenclature)으로 보고를 하였다. 특히 $\mathrm{HLA}-\mathrm{C}$ 의 경우 혈 청형이 기대결과에 어긋나는 경우가 10 건 $(6 \%, 10 / 166)$ 있었 는데 잘못된 혈청형을 보고한 기관은 1 기관 $(0.6 \%)$ 이었으며 나머지 9 기관(5.4\%)의 경우에는 broad specificity를 보고한 경우였다. 이는 일부 $\mathrm{SSP}$ 시약에서 $\mathrm{Cw} 9$ 와 $\mathrm{Cw} 10$ 을 구분하지 못하는 경우가 있어 이에 해당될 것으로 생각되었다(Table 3).

$\mathrm{HLA}-\mathrm{DR}$ 에 대한 저해상도와 고해상도 결과에 대한 정답률 은 각각 $100 \%$ (264/264)와 99\% (113/114)이었다. 한 기관에 서 고해상 $\mathrm{DR}$ 형을 표기 시 $\mathrm{DRB1}{ }^{*} 11: 01 / \mathrm{DRB1} 12: 01$ 이 아 닌 $D R^{*} 11: 01 / D R^{*} 12: 01$ 로 잘못된 용어표기법으로 보고를 하 였다. HLA-DQ에 대한 저해상도와 고해상도 결과에 대한 정 답률은 각각 99\% (125/126)와 98\% (59/60)이었다. 저해상도 에서 한 기관이 $D Q B 1^{*} 06$ 을 $D Q B 1^{*} 01$ 로 보고하였으며, 고해 상도에서는 한 기관이 $D Q B 1^{*} 03: 01 /-$ 가 아닌 $D Q^{*} 03: 01 /$-로 잘못된 용어표기법으로 보고를 하였다(Table 4).

\section{3. 특수조직적합성 형별검사}

강직성 척수염(ankylosing spondylitis)과 관련성이 있는 HLA-B27형 검사는 1 차에는 56기관, 2 차에는 60 기관이 참여 하였다. 각 회차당 1 개의 양성 물질과 1 개의 음성물질을 배송 하였다. 혈청형 및 저해상도 수준의 결과로 판정하고 있어 유 세포분석법(flow cytometry, $\mathrm{FCM}$ )과 같은 세포면역학적 방 법과 polymerase chain reaction (PCR)을 기반으로 한 분자 유전학적 방법이 사용되고 있었다(Table 5). 대다수 상품화된 


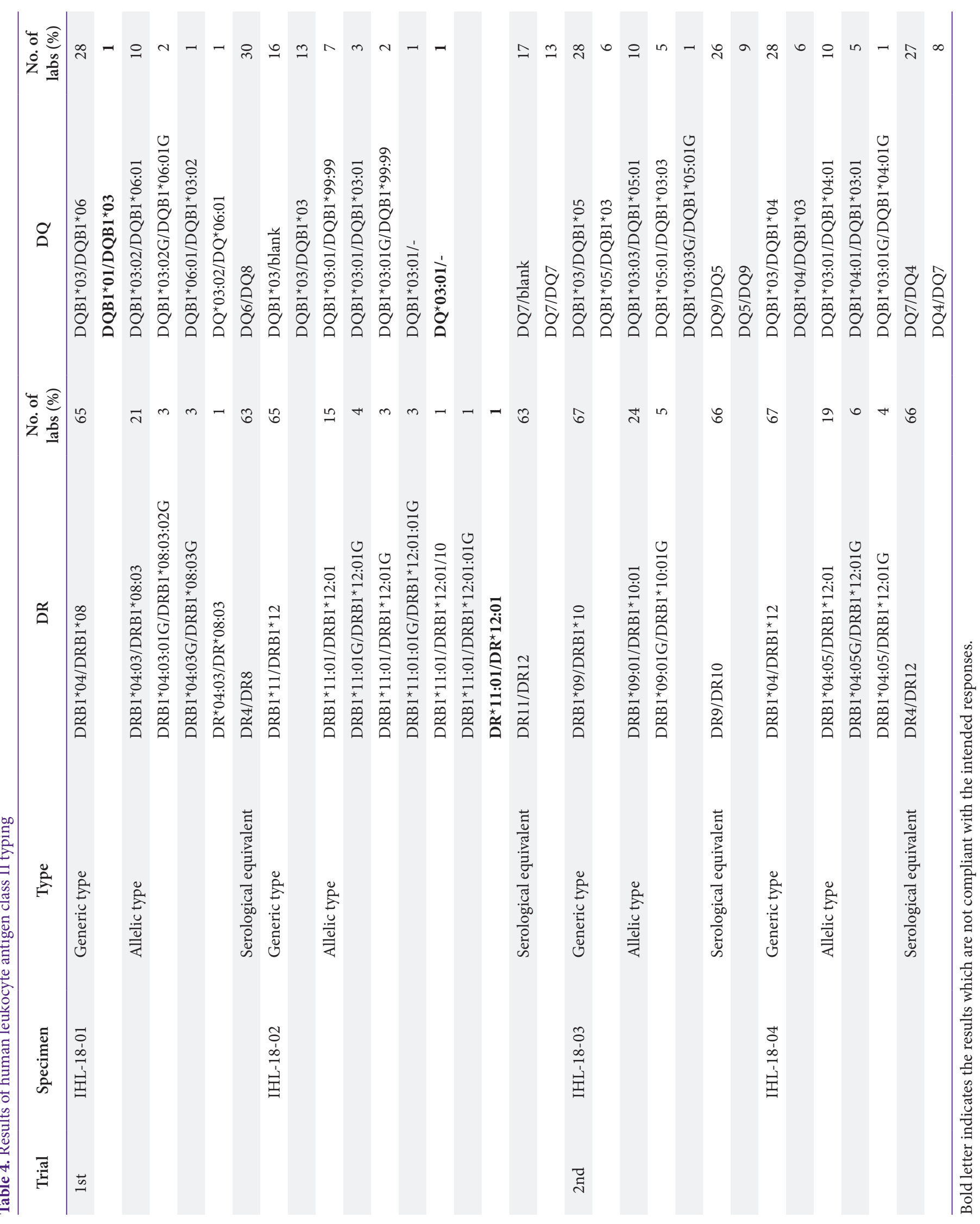


Table 5. Methods and results of HLA-B27 typing

\begin{tabular}{|c|c|c|c|c|c|c|}
\hline \multirow{3}{*}{ Methods/manufacturers } & \multicolumn{4}{|c|}{$1 \mathrm{st}$} & \multicolumn{2}{|c|}{ 2nd } \\
\hline & \multicolumn{2}{|c|}{ IB27-18-01 } & \multicolumn{2}{|c|}{ IB27-18-02 } & \multirow{2}{*}{$\begin{array}{c}\text { IB27-18-03 } \\
\text { Present }\end{array}$} & \multirow{2}{*}{$\begin{array}{c}\text { IB27-18-04 } \\
\text { Absent }\end{array}$} \\
\hline & Present & Absent & Present & Absent & & \\
\hline Becton Dickinson HLA-B27 kit & & 1 & 1 & & 2 & 2 \\
\hline Beckman Coulter Inc. & & 1 & 1 & & & \\
\hline BioCore HLA-B*27 PCR kit & & 8 & 8 & & 8 & 8 \\
\hline Bioneer AccuPower HLA-B27 Real-Time PCR kit & & 5 & 5 & & 5 & 5 \\
\hline Biosewoom HLA-B ${ }^{\star} 27$ PCR kit & & 16 & 16 & & 17 & 17 \\
\hline Biosewoom Real-Q HLA-B²7 Detection kit & & 11 & 11 & & 11 & 11 \\
\hline Other methods & & 2 & 2 & & 3 & 3 \\
\hline Others & & 2 & 2 & & 3 & 3 \\
\hline Total & 1 & 55 & 55 & 1 & 60 & 60 \\
\hline
\end{tabular}

Abbreviations: HLA, human leukocyte antigen; PCR, polymerase chain reaction.

시약을 사용하고 있었으나 자체 개발한 분자유전학적 검사법 으로 시행하고 있는 기관도 1 차에서는 2 기관, 2 차에서는 3 기관 있었다. 정답률은 1 차에서 $98 \%$ 로 PCR법으로 검사한 1 기관이 음성결과를 양성으로 보고하였으나, 2차에서는 $100 \%$ 였다.

\section{4. 조직적합성 교차시험검사}

각 회차당 2 개의 혈청과 2 개의 단핵구부유액을 배송하여 4 쌍씩의 교차시험을 시행하도록 하였으며 총 8쌍의 결과를 얻 었다. 1차에는 $\mathrm{T}$ 세포 교차시험에는 총 48기관이, $\mathrm{B}$ 세포 교 차시험에는 총 31 기관이 참여하였다. $\mathrm{T}$ 세포 교차시험의 경 우 민감도가 다른 두 가지 이상의 검사법을 반드시 시행하 도록 권고하고 있다. 전체적으로 29기관이 T세포-보체매개 세포독성법(T cell-complement dependent cytotoxicity)Direct법(T-CDC-Direct법), T-CDC-anti-human globulin 법(T-CDC-AHG법)과 T-flow cytometry법(T-FCM법)을 모 두 시행하였고, 14 기관이 T-CDC-Direct법과 T-CDC-AHG 법을 시행 보고하였다. 각각 2기관씩은 T-CDC-Direct법과 T-FCM법을 그리고 T-CDC-AHG법과 T-FCM법을 시행하 였으며, 1 기관은 T-FCM법 결과만을 보고하였다. B세포 교차 시험의 경우 11 기관에서 B-CDC-Direct법과 B-FCM법 결과 를 모두, 8 기관에서는 $\mathrm{B}-\mathrm{CDC}-$ Direct법 결과만을 그리고 12 기관에서는 B-FCM법 결과만을 보고하였다. 2차에는 T세포 교차시험에는 총 48 기관이, $\mathrm{B}$ 세포 교차시험에는 총 33 기관이
참여하였다. 전체적으로 30 기관이 T-CDC-Direct법, T-CDC$\mathrm{AHG}$ 법과 T-FCM법을 모두 시행하였고, 14 기관이 T-CDCDirect법과 T-CDC-AHG법을 시행 보고하였다. 두 기관은 $\mathrm{T}-\mathrm{CDC}-\mathrm{AHG}$ 법과 $\mathrm{T}-\mathrm{FCM}$ 법을 시행하였고 각각 1 기관씩 은 T-CDC-Direct법과 T-FCM법 결과만을 보고하였다. B세 포 교차시험의 경우 10 기관에서 B-CDC-Direct법과 B-FCM 법을, 7 기관에서는 $\mathrm{B}-\mathrm{CDC}-$ Direct법을, 그리고 12 기관에서 는 B-FCM법 결과만을 보고하였다. 그러나 T세포에서 1 기관 과 $\mathrm{B}$ 세포에서 4 기관이 결과를 입력하지 않았다. 각 세포와 검 사법에 따른 결과를 Table 6 에 정리하였는데, 정성결과에 따 라 결과 판정을 시행하였으며, 반정량 희석배수 결과는 기관 간의 결과 분포를 파악하기 위하여 함께 표기하였다. IX-1801+ IX-18-03 T-CDC법과 IX-18-05+IX-18-07 T-CDC와 $\mathrm{B}-\mathrm{CDC}$ 법 결과는 각각 더 민감한 검사인 T-FCM과 B-FCM 법 결과에서 $80 \%$ consensus에 도달하지 못하여 Code 505 를 적용하여 판정 제외하였고, 그 외는 각 검사법 내에서 $80 \%$ consensus에 도달하지 못하여 판정 제외하였다. 각 교차시 험 검체에서 부적합 결과의 비율은 Code 505에 해당하는 결 과들을 제외하고 도출하였는데, 1 차 $\mathrm{T}$ 세포 교차시험에서는 0\%-7.3\% (평균, 2.7\%; 10/372), B세포 교차시험에서는 0\%$17.4 \%$ (평균, $5.4 \% ; 7 / 130$ )이었으며, 2차 $\mathrm{T}$ 세포 교차시험에 서는 0\%-4.8\% (평균, 3.6\%; 12/330), B세포 교차시험에서 는 0\%-17.5\% (평균, $6.6 \% ; 8 / 120$ )이었다. 
Eun-Suk Kang • Histocompatibility EQA

Table 6. Methods and results of human leukocyte antigen crossmatching

\begin{tabular}{|c|c|c|c|c|c|c|c|c|c|c|c|c|c|}
\hline Trial & Specimen & Methods & Total & $\begin{array}{l}\text { Nega- } \\
\text { tive }\end{array}$ & $\begin{array}{c}\text { Posi- } \\
\text { tive }\end{array}$ & $1: 1$ & $1: 2$ & $1: 4$ & $1: 8$ & $1: 16$ & $1: 32$ & $>1: 32$ & $\begin{array}{l}\text { Intended } \\
\text { response }\end{array}$ \\
\hline \multirow[t]{20}{*}{1 st } & IX-18-01+IX-18-03 & T-CDC-Direct & 45 & 45 & 0 & & & & & & & & Code 505 \\
\hline & & T-CDC-AHG & 45 & 38 & 7 & 2 & 3 & 1 & & 1 & & & Code 505 \\
\hline & & T-FCM & 34 & 23 & 11 & & & & & & & & Code 505 \\
\hline & & B-CDC-Direct & 19 & 12 & 7 & 2 & 2 & & 1 & 1 & 1 & & Code 505 \\
\hline & & B-FCM & 23 & 4 & 19 & & & & & & & & Positive \\
\hline & IX-18-01+IX-18-04 & T-CDC-Direct & 45 & 42 & 3 & & 1 & 2 & & & & & Negative \\
\hline & & T-CDC-AHG & 45 & 41 & 4 & 1 & & & 3 & & & & Negative \\
\hline & & T-FCM & 34 & 32 & 2 & & & & & & & & Negative \\
\hline & & B-CDC-Direct & 19 & 2 & 17 & & & & 1 & 4 & 9 & 3 & Positive \\
\hline & & B-FCM & 23 & 0 & 23 & & & & & & & & Positive \\
\hline & IX-18-02+IX-18-03 & T-CDC-Direct & 45 & 0 & 45 & & 3 & 2 & 11 & 22 & 5 & 2 & Positive \\
\hline & & T-CDC-AHG & 45 & 0 & 45 & & & 2 & 2 & 7 & 23 & 11 & Positive \\
\hline & & T-FCM & 34 & 0 & 34 & & & & & & & & Positive \\
\hline & & B-CDC-Direct & 19 & 0 & 19 & & & & & 2 & 13 & 4 & Positive \\
\hline & & B-FCM & 23 & 0 & 23 & & & & & & & & Positive \\
\hline & IX-18-02+IX-18-04 & T-CDC-Direct & 45 & 45 & 0 & & & & & & & & Negative \\
\hline & & T-CDC-AHG & 45 & 45 & 0 & & & & & & & & Negative \\
\hline & & T-FCM & 34 & 33 & 1 & & & & & & & & Negative \\
\hline & & B-CDC-Direct & 19 & 11 & 8 & 1 & 3 & 2 & 1 & 1 & & & Code 505 \\
\hline & & B-FCM & 23 & 1 & 22 & & & & & & & & Positive \\
\hline \multirow[t]{20}{*}{2 nd } & IX-18-05+IX-18-07 & T-CDC-Direct & 45 & 45 & 0 & & & & & & & & Code 505 \\
\hline & & T-CDC-AHG & 46 & 45 & 1 & & & & 1 & & & & Code 505 \\
\hline & & T-FCM & 34 & 27 & 7 & & & & & & & & Code 505 \\
\hline & & B-CDC-Direct & 18 & 11 & 7 & 3 & & & 1 & & 3 & & Code 505 \\
\hline & & B-FCM & 22 & 6 & 16 & & & & & & & & Code 505 \\
\hline & IX-18-05+IX-18-08 & T-CDC-Direct & 45 & 5 & 40 & 3 & 8 & 8 & 2 & 5 & 11 & 3 & Positive \\
\hline & & T-CDC-AHG & 46 & 1 & 45 & & 3 & 4 & 4 & 7 & 15 & 12 & Positive \\
\hline & & T-FCM & 34 & 0 & 34 & & & & & & & & Positive \\
\hline & & B-CDC-Direct & 18 & 0 & 18 & 1 & & & 2 & 1 & 10 & 4 & Positive \\
\hline & & B-FCM & 22 & 0 & 22 & & & & & & & & Positive \\
\hline & IX-18-06 +IX-18-07 & T-CDC-Direct & 45 & 31 & 14 & 7 & 4 & & & 2 & 1 & & Code 505 \\
\hline & & T-CDC-AHG & 46 & 4 & 42 & 6 & 11 & 10 & 6 & 3 & 5 & 1 & Positive \\
\hline & & T-FCM & 34 & 0 & 34 & & & & & & & & Positive \\
\hline & & B-CDC-Direct & 18 & 4 & 14 & 2 & 3 & 4 & 1 & 1 & 3 & & Positive \\
\hline & & B-FCM & 22 & 3 & 19 & & & & & & & & Positive \\
\hline & IX-18-06+IX-18-08 & T-CDC-Direct & 45 & 44 & 1 & 1 & & & & & & & Negative \\
\hline & & T-CDC-AHG & 46 & 45 & 1 & & & 1 & & & & & Negative \\
\hline & & T-FCM & 34 & 34 & 0 & & & & & & & & Negative \\
\hline & & B-CDC-Direct & 18 & 17 & 1 & 1 & & & & & & & Negative \\
\hline & & B-FCM & 22 & 21 & 1 & & & & & & & & Negative \\
\hline
\end{tabular}

Abbreviations: T-CDC, T cell-complement dependent cytotoxicity; AHG, anti-human globulin; FCM, flow cytometry; B-CDC, B cellcomplement dependent cytotoxicity. 
Table 7. Kits and results of human leukocyte antigen antibody screening

\begin{tabular}{|c|c|c|c|c|c|}
\hline \multirow{3}{*}{ Manufacturers/kits } & \multicolumn{2}{|c|}{1 st } & \multicolumn{2}{|c|}{ 2nd } & \multirow{3}{*}{$\begin{array}{l}\text { Intended } \\
\text { response }\end{array}$} \\
\hline & IB27-18-01 & IB27-18-02 & IB27-18-03 & IB27-18-04 & \\
\hline & Present & Present & Present & Present & \\
\hline Lifecodes LifeScreen Deluxe & 9 & 9 & 8 & 8 & Present \\
\hline Total & 20 & 20 & 19 & 19 & \\
\hline
\end{tabular}

The kits were from the following companies: One Lambda (Canoga Park, CA, USA) and Immucor Lifecodes (Stamford, CT, USA).

\section{5. 조직적합성 항체검사}

각 회차당 2 개의 혈청을 배송하여 총 4 개의 물질에 대한 결과를 얻었다. 조직적합성 항체검사는 선별과 동정 모두 Immucor Lifecodes사(Stamford, CT, USA)와 One Lambda 사(Canoga Park, CA, USA)의 luminex microbead array 기 반의 시약을 사용하여 이루어지고 있었다.

선별검사의 경우 1 차에 20 기관과 2 차에 19 기관이 회신하 였는데, 모두 적합한 결과를 보고하였다(Table 7). 동정검사 의 경우에는 여러 개의 항원이 한 비드에 부착되어 있는 시약 을 이용한 표현형(phenotyping) 검사와 한 개의 항원이 한 비 드에 부착되어 있는 시약을 이용한 단일항원형 동정(single antigen identification) 검사결과를 1 차에서는 각각 12 개와 22 개의 기관에서(Tables 8, 9), 2 차에서는 각각 11 개와 22 개 의 기관에서(Tables 10,11$)$ 보고하였다. 항원 동정검사에 대 해서는 정성결과로 평가하였고, \% PRA (percent reactive antibody)와 동정항원성에 대해서는 평가하지 않았다. 부적 합 판정을 받은 기관은 없었으나 동일한 시약을 사용하는 기 관들 내에서도 보고한 항원성 및 항원의 수는 다양하였으며, $\% \mathrm{PRA}$ 의 보고범위도 매우 넓었다. 예를 들어 IHA-18-02 class I의 경우 $4 \%-95 \% \mathrm{PRA}$ 의 분포를 보였는데, 그 안에서 동일한 항원성을 보고하면서도 $\% \mathrm{PRA}$ 는 다른 기관들이 존재 하였다.

\section{고찰}

조직적합성검사 신빙도조사는 대한임상점사정도관리협회 에서는 2018년도에 처음으로 도입, 시행되었다. 기존 대한진 단검사의학회에서 시행해 왔던 신빙도조사의 범위 및 입력방 식을 대한임상검사정도관리협회의 차세대전산시스템에 반영 하였다. 그러나 결과 분석방법 및 방향 그리고 보고서 양식에 있어서는 차세대전산시스템이 가진 정형화된 방식으로 인하 여 그간 시행해 왔던 방식과는 상당한 차이가 있었고, 이로 인 해 참여기관에서 보고서를 통해 자체 및 참여기관들의 결과를
파악하고 해석하는 데 어려움이 있었다.

조직적합성검사 프로그램 참여 및 회신기관은 1 차와 2 차가 동일하지는 않았다. 2차에서 HLA 형별검사 중 고해상도 결과 보고기관이 2군데 늘어났으며, HLA-B27형 검사는 4군데 늘 어났다. $\mathrm{B}$ 세포 교차시험의 경우에도 보고기관이 2 기관 증가하 였으나 4기관에서 not available (NA)로 입력하여 실제 분석 결과 수는 2차에서 감소하였다.

HLA 형을 기술하는 방식은 2010년 개정된 World Health Organization (WHO) nomenclature 표기법에 따른다[3]. Lee와 Park [4]은 한국인의 HLA 대립유전자를 중심으로 새 명명법을 쉽게 적용할 수 있도록 이를 간추려 보고한 바 있다. $\mathrm{HLA}$ 형별검사 결과 중 잘못된 형을 보고한 경우는 단 한 건이 었으며 오히려 표기법의 오류가 4건 있었다. 고해상도 결과 중 $\mathrm{HLA}-\mathrm{C}$ 대립유전자 표기 시 대문자 $C$ 만을 사용하는 대신 혈 청형과 같은 $C W$ 로 표기한 경우가 2건, HLA-DR 대립유전자 표기 시 표적 유전자부위인 beta-chain을 표기하는 DRB1 대 신 혈청형과 같은 $D R$ 로 표기한 경우가 2건 있었다. $\mathrm{HLA}-\mathrm{C}$ 혈청형의 경우 다수의 기관에서 $C^{*} 03: 04$ 과 $C^{*} 03: 03$ 를 $\mathrm{Cw} 9$ 와 $\mathrm{Cw} 10$ 으로 구분하지 않고 broad specificity인 Cw3으로 보 고하였다. 이는 일부 PCR-SSP 시약에서 이 두 혈청형을 구 분할 수 없어서인 것으로 생각되며, 혈청형과 저해상도 유전 자형 결과가 널리 이용되고 있는 장기이식분야에서는 HLA-C 의 임상적 중요성이 낮아 이를 구분하여 보고하지 못하는 것 이 검사실의 수행능력에 미치는 영향은 미미할 것으로 생각 된다. IHL-18-02와 IHL-18-03은 $C^{*} 14: 02$ 를 가진 검체인데, HLA Dictionary 2008 (https://www.ebi.ac.uk/cgi-bin/ipd/ imgt/hla/get_dictionary.cgi)에 따르면 WHO에서 정한 혈청 형(WHO assigned type)이 결정되어 있지 않으며 전문가들이 정한 혈청형(expert assigned type)은 $\mathrm{Cw} 1$ 또는 blank로 제 안되고 있다. 입력 시 정해진 혈청형이 없는 경우 other로 표 기하도록 하였는데, 대다수의 기관은 other 또는 blank로 보 고하였으나 일부는 $\mathrm{Cw} 14$ 로 보고하였으며 1기관만이 $\mathrm{Cw} 1$ 로 보고하였다. 


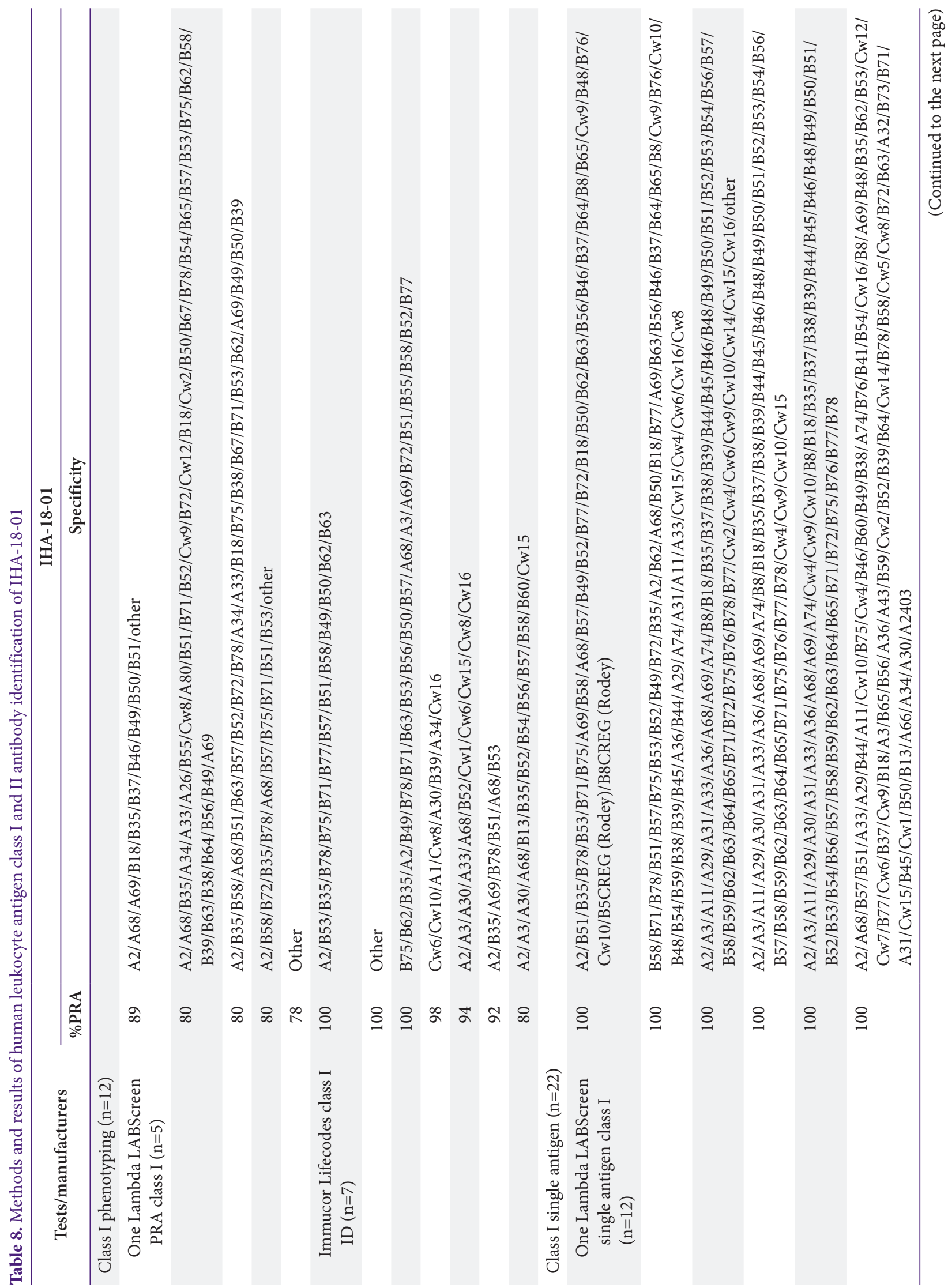




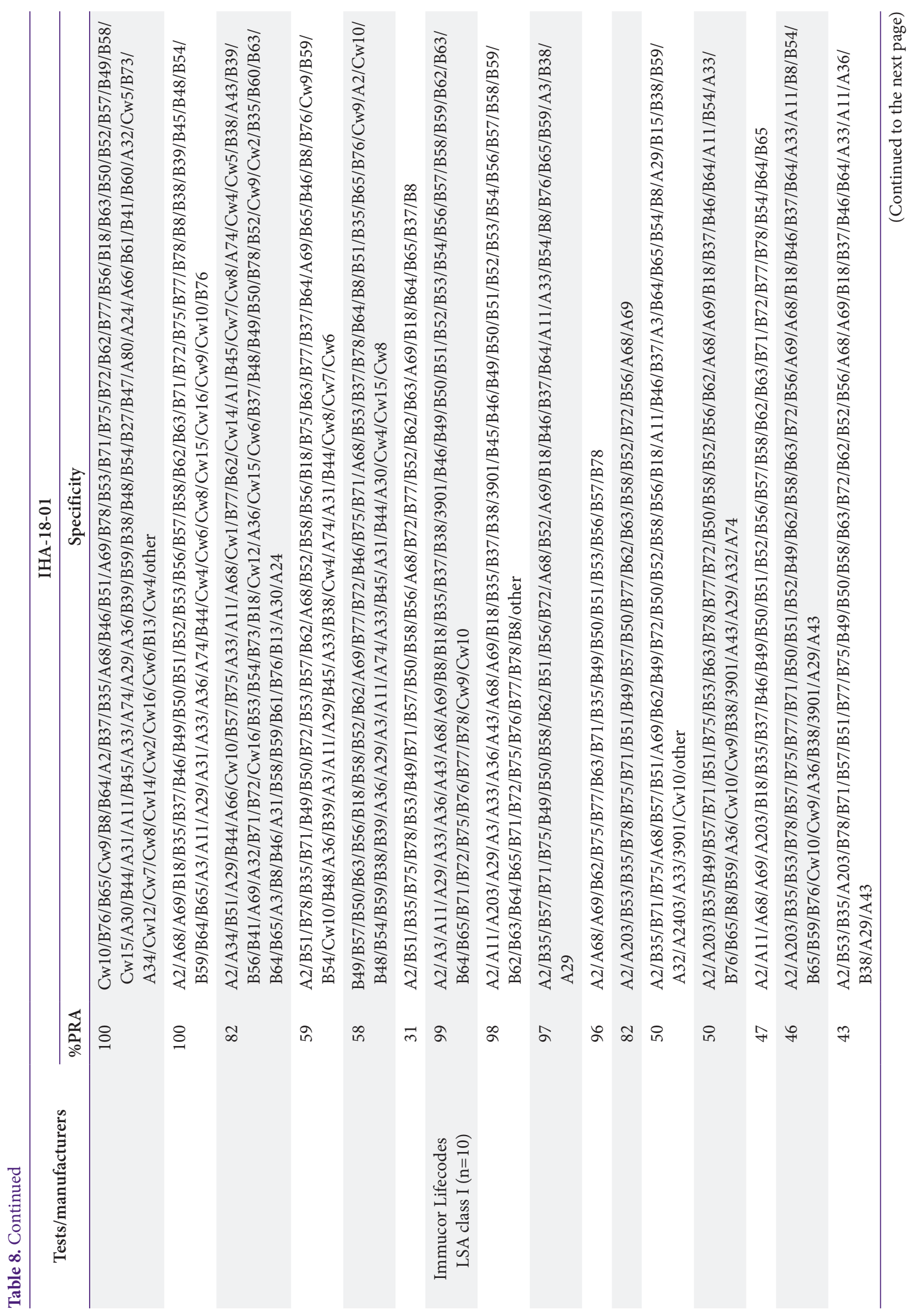




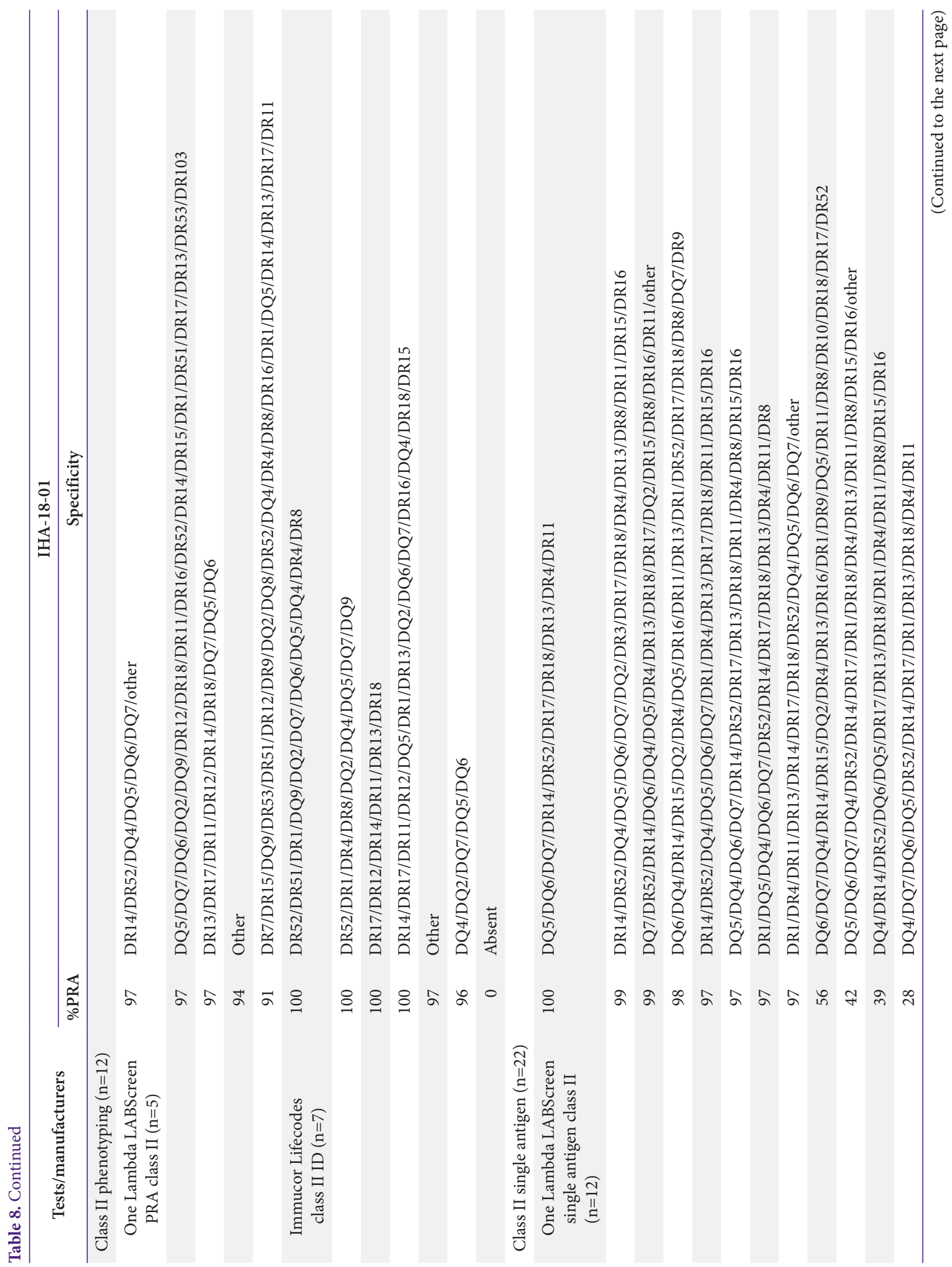




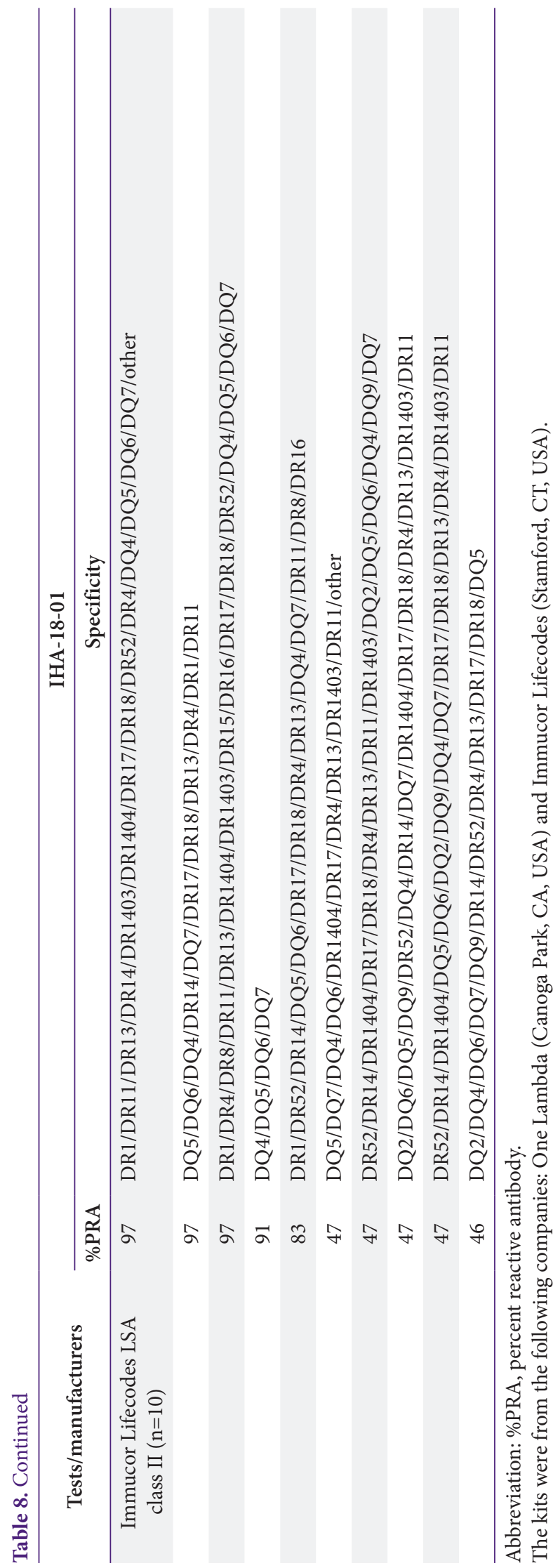

$\mathrm{HLA}-\mathrm{B} 27$ 형 검사는 대다수의 기관은 PCR 기반의 전용 상 품화 시약을 사용하고 있었으나, 2기관에서 $\mathrm{FCM}$ 법을 사용 하고 있었으며, 3 기관은 자체 개발한 분자유전학적 방법을 사 용하고 있었고, other method로 보고한 기관 중에는 상품화 HLA-B typing용 시약으로 검사 후 HLA-B27 유무를 판정하 는 기관도 있는 것으로 파악되었다.

$\mathrm{HLA}$ 교차시험 시행기관들에서 변화는 $\mathrm{T}-\mathrm{FCM}$ 법이 T-CDC-Direct법과 T-CDC-AHG법 중 한 가지를 대체하거 나 B-CDC-Direct법 대신 B-FCM법만을 시행하는 기관이 점 차 증가하고 있다는 것이다. $\mathrm{FCM}$ 법의 경우 시험 검체와 음 성대조물질 간의 median fluorescence intensity (MFI) ratio 를 기반으로 정성 판정을 하고 이를 반정량 결과로 표기하게 되는데, 각 기관마다 다른 cut off를 가지고 있으며 기존 CDC 법에서 널리 사용되어온 희석배수 반정량 표기와 연계하여 결 과를 해석하기가 어렵다. 또한 기존 대한진단검사의학회 외부 정도관리 결과에서 각 기관의 MFI ratio를 분석하였을 때 매 우 넓은 범위에 걸쳐 분포하고 있음을 관찰하였는데, 이는 $\mathrm{Yu}$ 등[5]이 2015년 대한진단검사의학회 주관 HLA 교차시험 표 준화사업의 일환으로 설문조사를 통해 조사 보고한 바와 같 이 기관마다 다양한 조건에서 유세포 교차시험을 시행하고 있 기 때문으로 생각된다. 당시 검사기관들을 대상으로 검사법 워크숍을 시행하여 일부 개선이 이루어졌으리라 기대되나 향 후 표준화된 프로토콜의 개발 및 적용과 같은 좀 더 적극적인 $\mathrm{HLA}$ 유세포 교차시험 표준화를 위한 노력이 필요하겠다. 결 과 판정에 있어서는 민감도가 다른 두 가지 이상의 검사법을 반드시 시행하도록 권고하고 있는 바 민감도가 높은 검사에 서 $80 \%$ 이상의 일치를 보이지 않는 경우 하위검사의 결과는 Code 505로 기술하고 판정 제외하였다. 그러나 이는 College of American Pathologist 정도관리프로그램의 판정기준에 따 라 민감도가 높은 검사(T-FCM법 또는 T-CDC-AHG법)에서 $10 \%$ 이상의 양성결과를 보이는 경우 하위검사에서 $80 \%$ 이상 의 일치를 보이지 않더라도 양성결과는 판정 제외, 음성결과 는 unacceptable로 판정하던 기존의 판정기준에 비하여 신빙 도조사 결과에 대한 판별력이 떨어지므로 향후 판정기준의 개 선이 이루어져야 하겠다. 교차시험 검체에서 부적합 결과의 비 율은 T세포에서 1, 2차 평균 3.1\% (22/702)인데 반하여 B세 포에서는 6.0\% (15/250)으로 높았으며, B세포 교차시험의 경 우 2차에서 4기관이 NA로 입력하였다. 이는 B세포 교차시험 이 상대적으로 기관 간 변이에 취약함을 시사하는데, 말초혈 액 내 $\mathrm{B}$ 세포 수가 적고 분리 시 회수율이 낮으며 나일론 울 컬 럼을 사용할 경우 추가적인 조작으로 생존도가 감소할 수 있는 점 등을 고려 시 예상할 수 있는 결과이다. 그러므로 B세포 취 
Journal of LABORATORY MEDICINE and QUALITY ASSURANCE

Eun-Suk Kang • Histocompatibility EQA

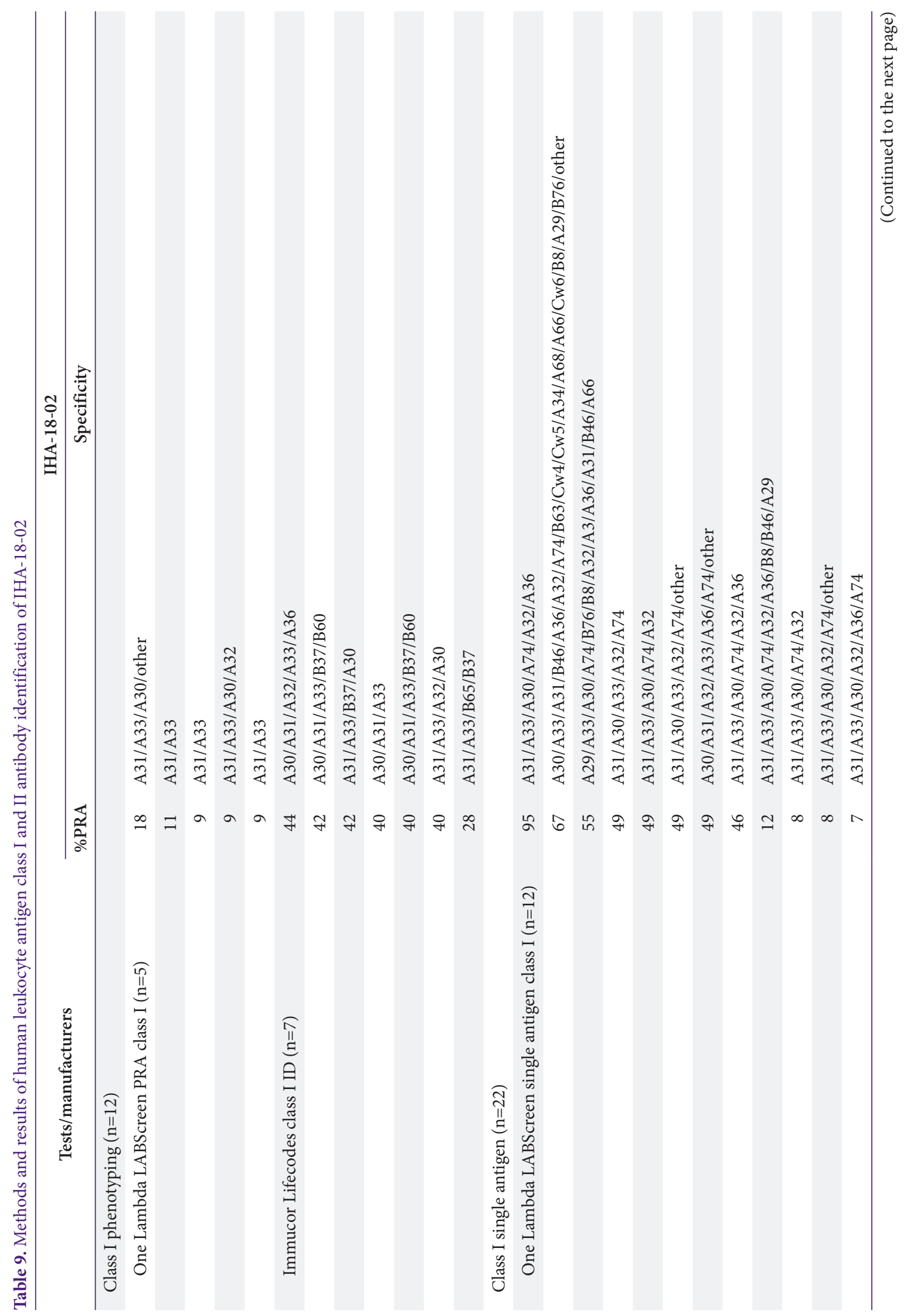




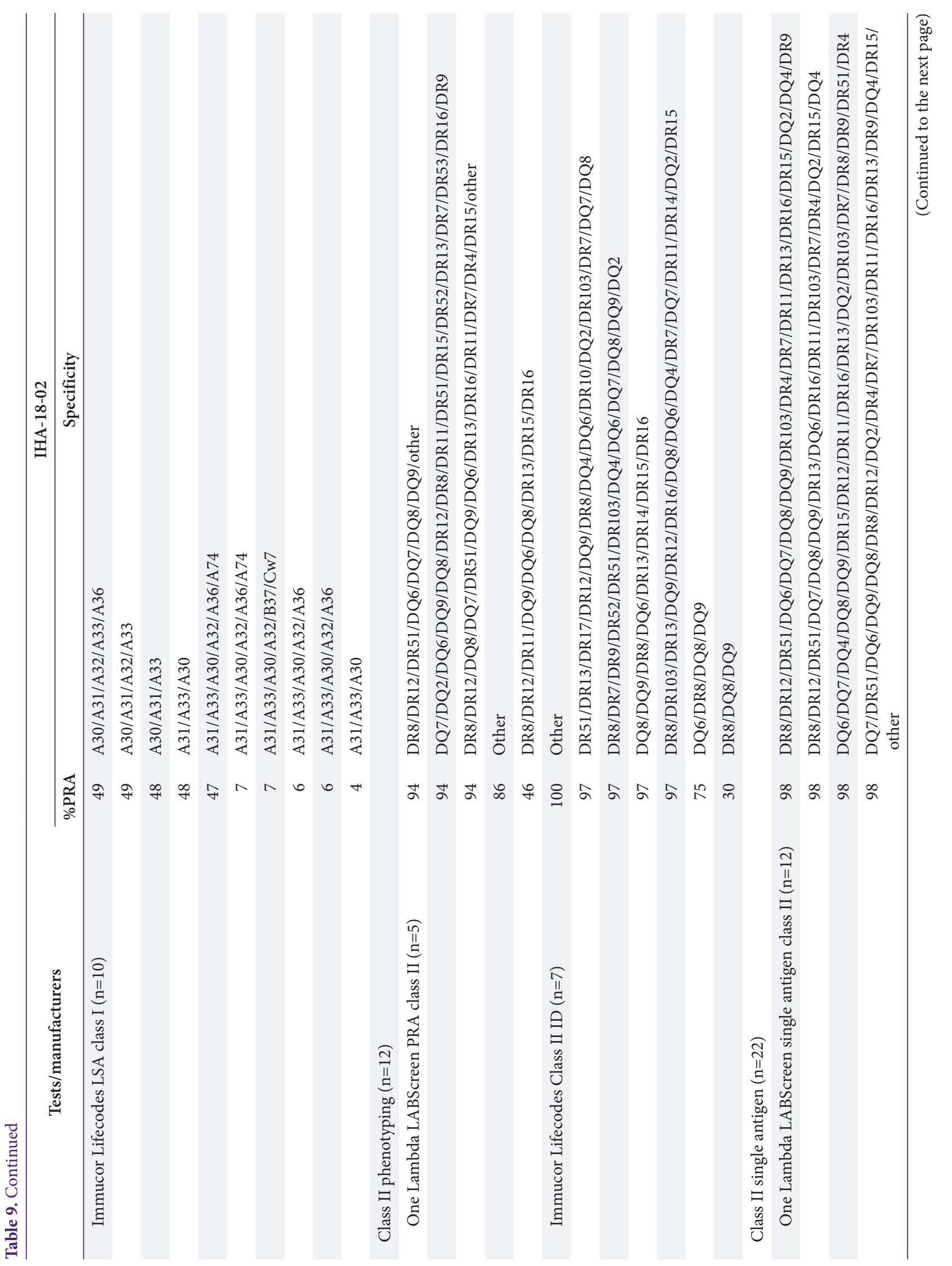




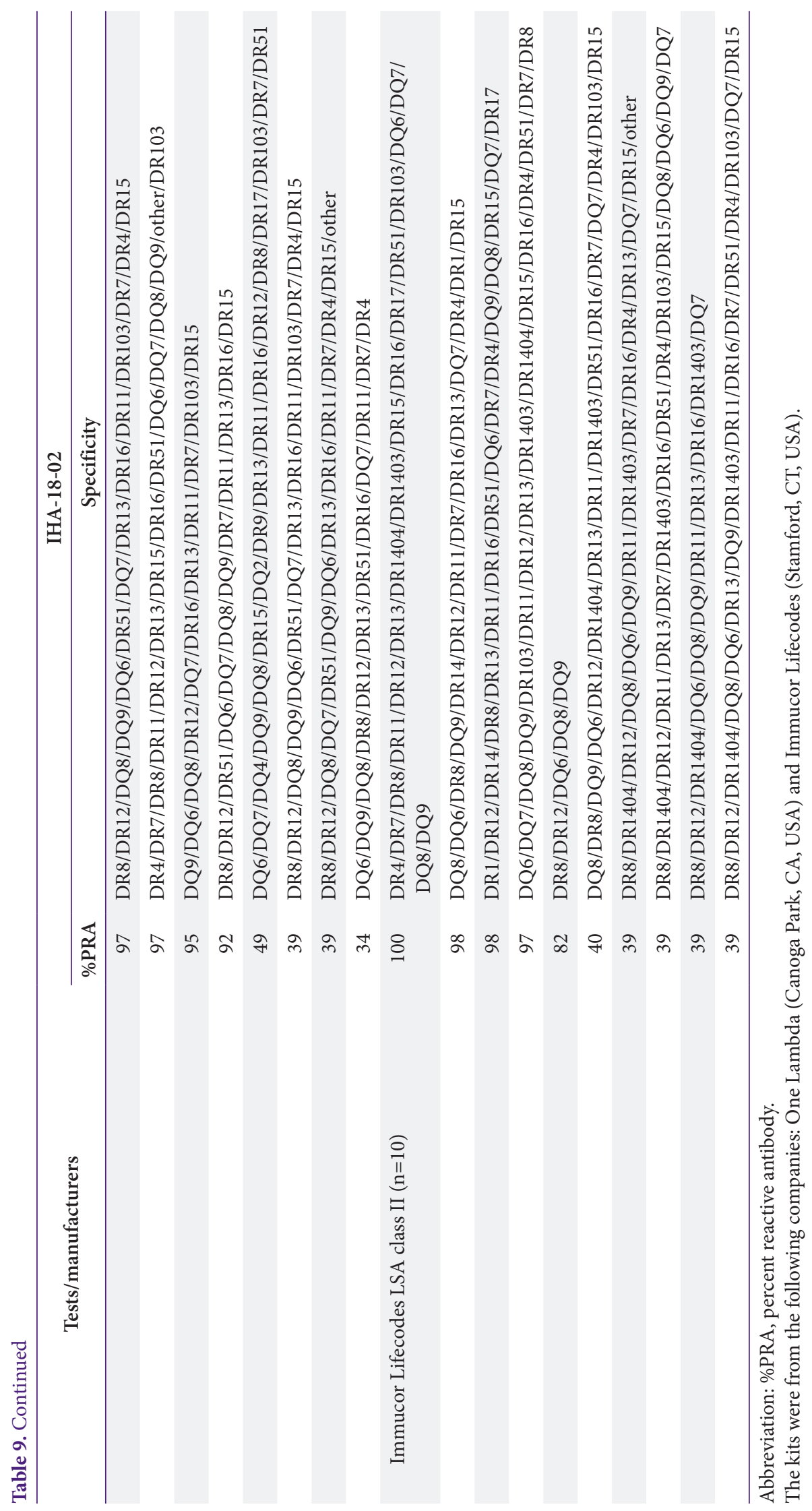



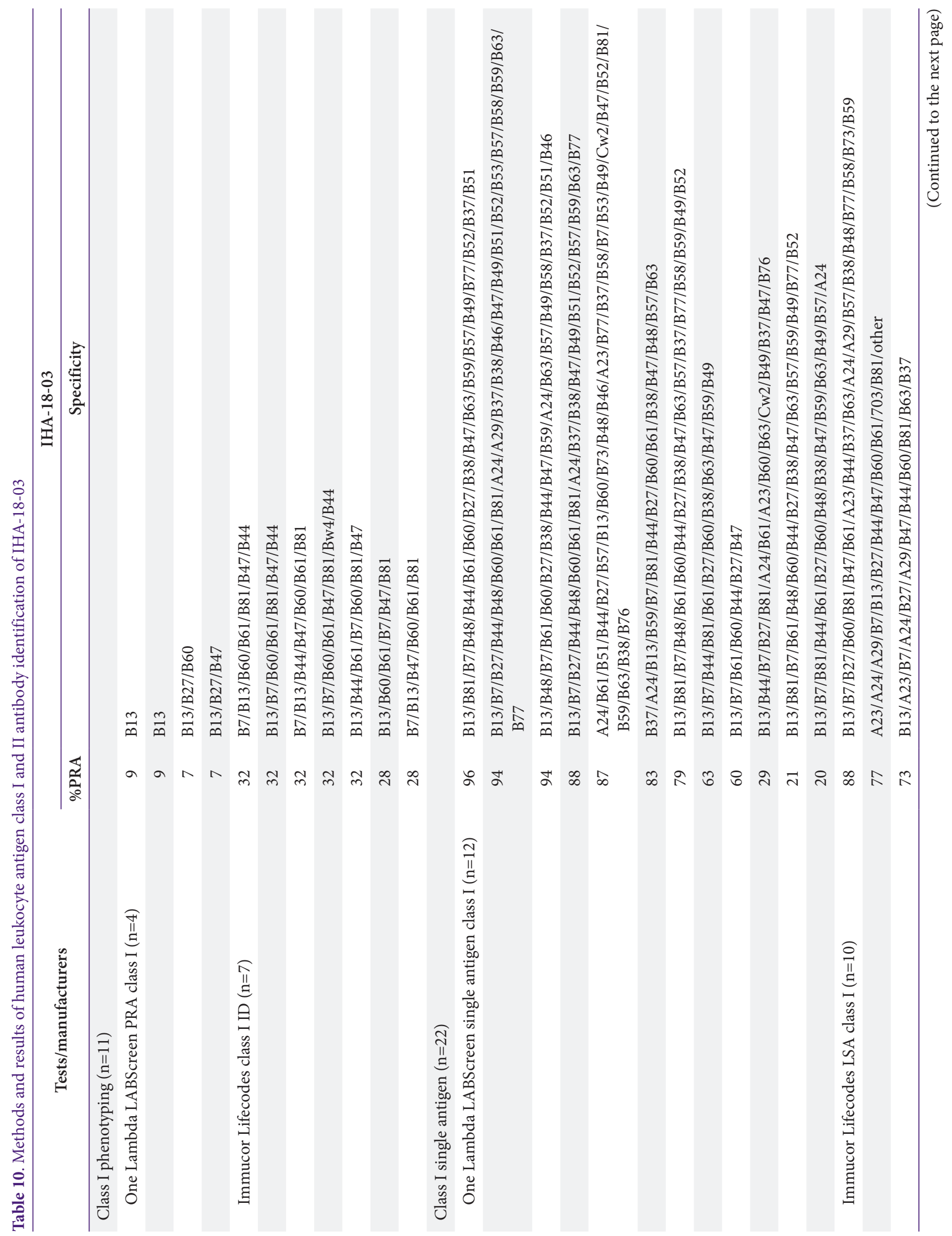


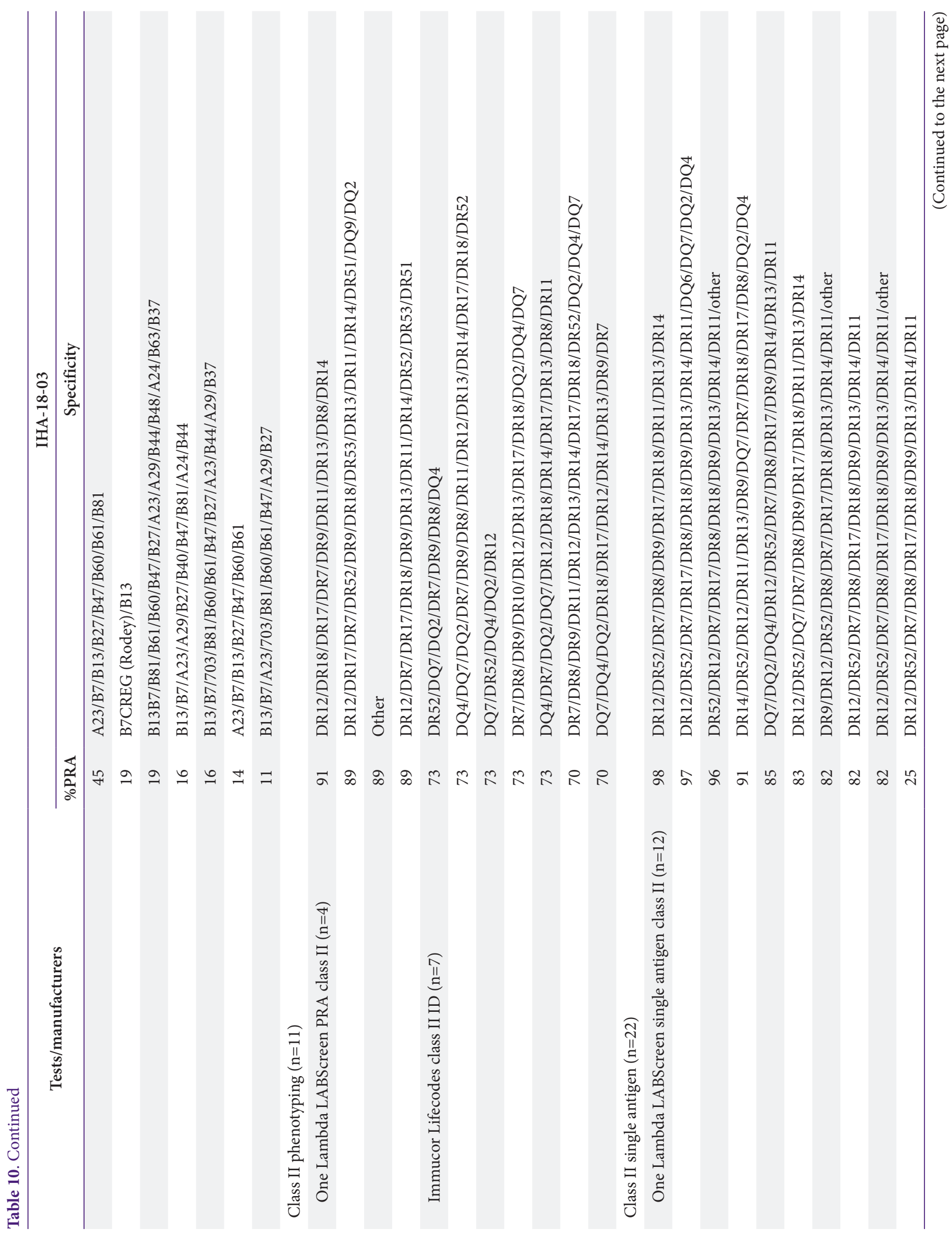




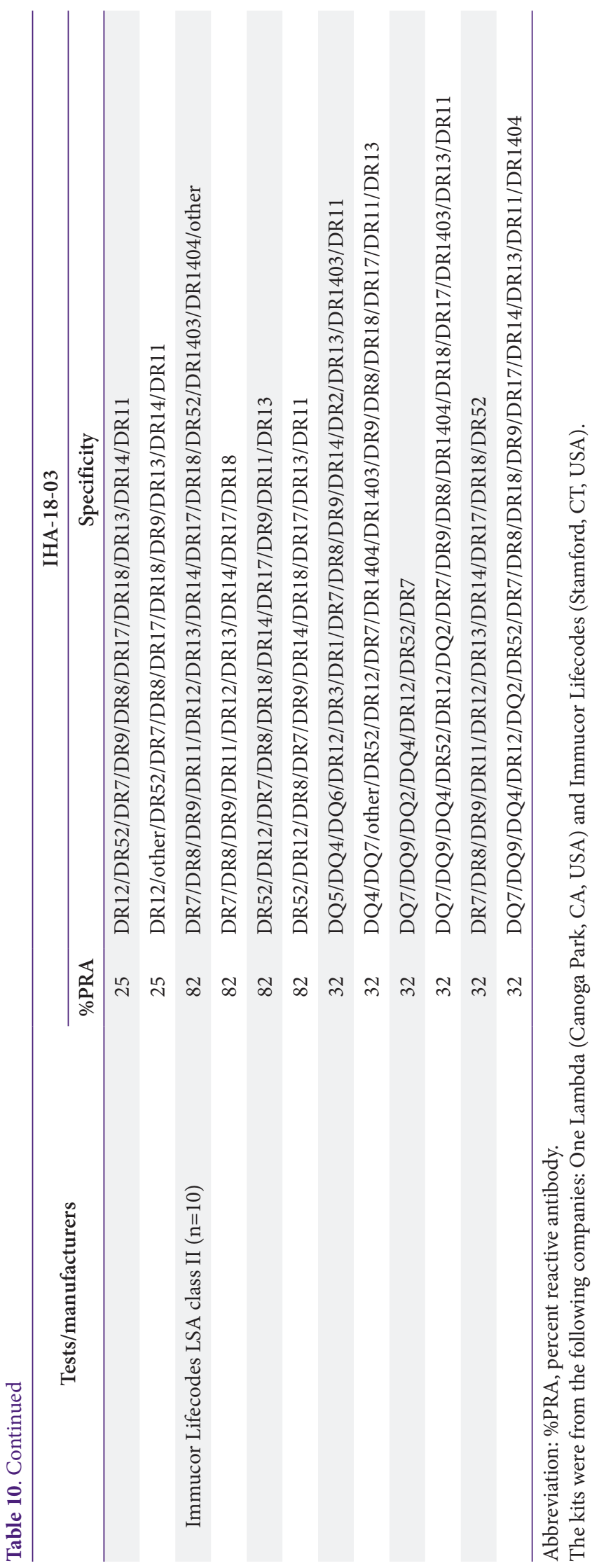

급 및 검사시행 시 숙련도가 더 향상되도록 개선활동이 필요하 겠다.

HLA 항체 선별 및 동정검사는 국내 모든 기관들이 luminex microbead array법으로 시행하고 있다. 국내에서 사용되고 있는 Immucor Lifecodes사와 One Lambda사의 시약들은 자 체적으로 양성 판정기준을 제시하고 있으나 절대적인 기준 은 없으며 판독자에 따라 CREG (cross reactive group)나 검 체의 특성을 고려하여 양성 여부를 판정하게 된다. 그러므로 현 시점에서 동정된 항원성의 종류나 수를 평가하기는 어렵 다. \% PRA는 동정한 항원성에 따라서 결정되지만 이를 도출 하기 위하여 어떤 데이터베이스를 기반으로 어떤 공식에 의하 여 계산하는가에 따라 달라질 수 있다. 예를 들어 IHA-18-02 class I의 경우 4\%-95\% PRA의 분포를 보였는데, 13 개 기관에 서는 $46 \%$ 이상의 \% PRA를 보고하였고 9 개 기관에서는 $12 \%$ 이하의 $\% \mathrm{PRA}$ 를 보고하였다. 또한 동일한 항원성을 보고하 면서도 $\% \mathrm{PRA}$ 는 $95 \%$ 와 $7 \%$ 로, $48 \%$ 와 $4 \%$ 로 달리 보고한 기 관들이 존재하였다. 이는 한국인의 HLA 형별 자료에 기반한 \%calculated PRA (cPRA)를 도출하지 않고 시약 내에 포함 된 전체 비드 중 양성비드의 비율만을 계산하였을 가능성을 생 각해 볼 수 있다. 그러나 그와 같은 계산방식은 특정 인구집단 이 가진 HLA에 대한 감작 정도를 예측하는 PRA의 의미에 전 혀 맞지 않는다. 대한진단검사의학회 면역분과에서는 2015년 한국인 자료를 이용하여 web 기반 cPRA calculator (http:// cpra.inforang.com/form/form.html)를 만들었으며 이는 모 든 기관에서 무료로 사용할 수 있는데, 현재로서는 이를 이용 하여 \% PRA를 도출하는 것이 가장 적합하다고 할 수 있다. 시약 간 항원동정의 민감도는 동정된 항원의 수 또는 \% $\mathrm{PRA}$ 를 이용하여 비교할 수 있겠다. 그러나 기관 간 판독기준 및 $\% \mathrm{PRA}$ 보고기준의 다양함으로 인하여 현 시점에서는 어렵다. 분석에는 포함되지 않았지만 항원 표현형 검사를 시행하고 있 는 기관들이 1 차와 2 차에 각각 12 및 11 기관이 있었다. 수입시 약이기는 하나 $\% \mathrm{PRA}$ 를 도출하고, native 항원을 사용하므로 재조합 항원을 사용하는 단일항원 동정검사에서의 문제를 일 부 해결할 수 있다는 장점이 있으나 정확한 항원성을 동정하는 데는 한계가 있다.

2018년 처음으로 대한임상검사정도관리협회에 도입되어 시 행한 조직적합성검사 신빙도조사는 검체의 준비, 발송 및 결과 입력과정은 이전의 신빙도조사와 비교하여 순조로이 진행되 었으며, 각 항목에 대한 조사결과를 종합해 볼 때 대부분의 기 관이 매우 놓은 신빙도를 유지하고 있음을 확인하였다. 그러나 향후 HLA 교차시험의 판정기준 및 전반적인 보고서 양식의 개선은 이루어져야 할 것으로 생각된다. 


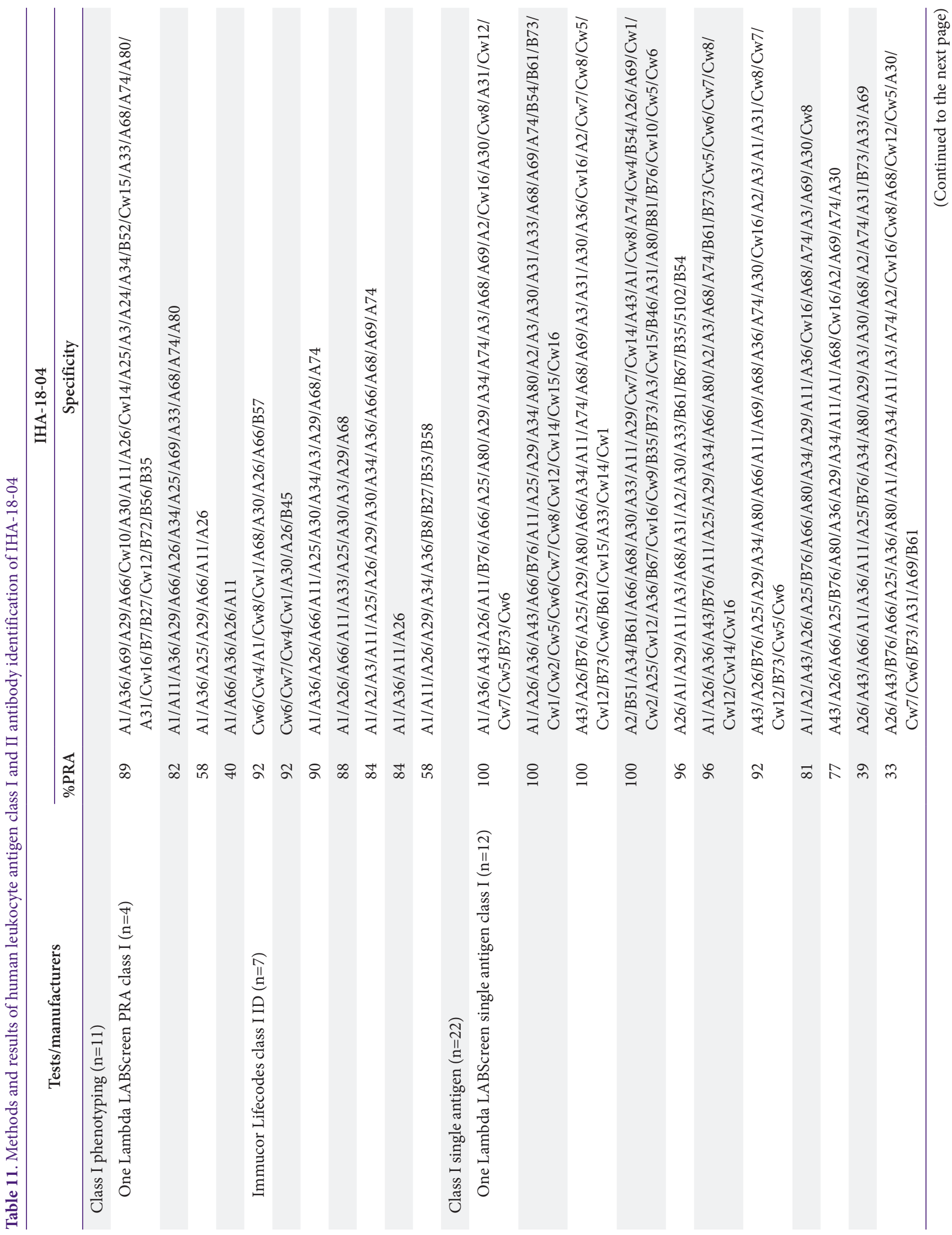



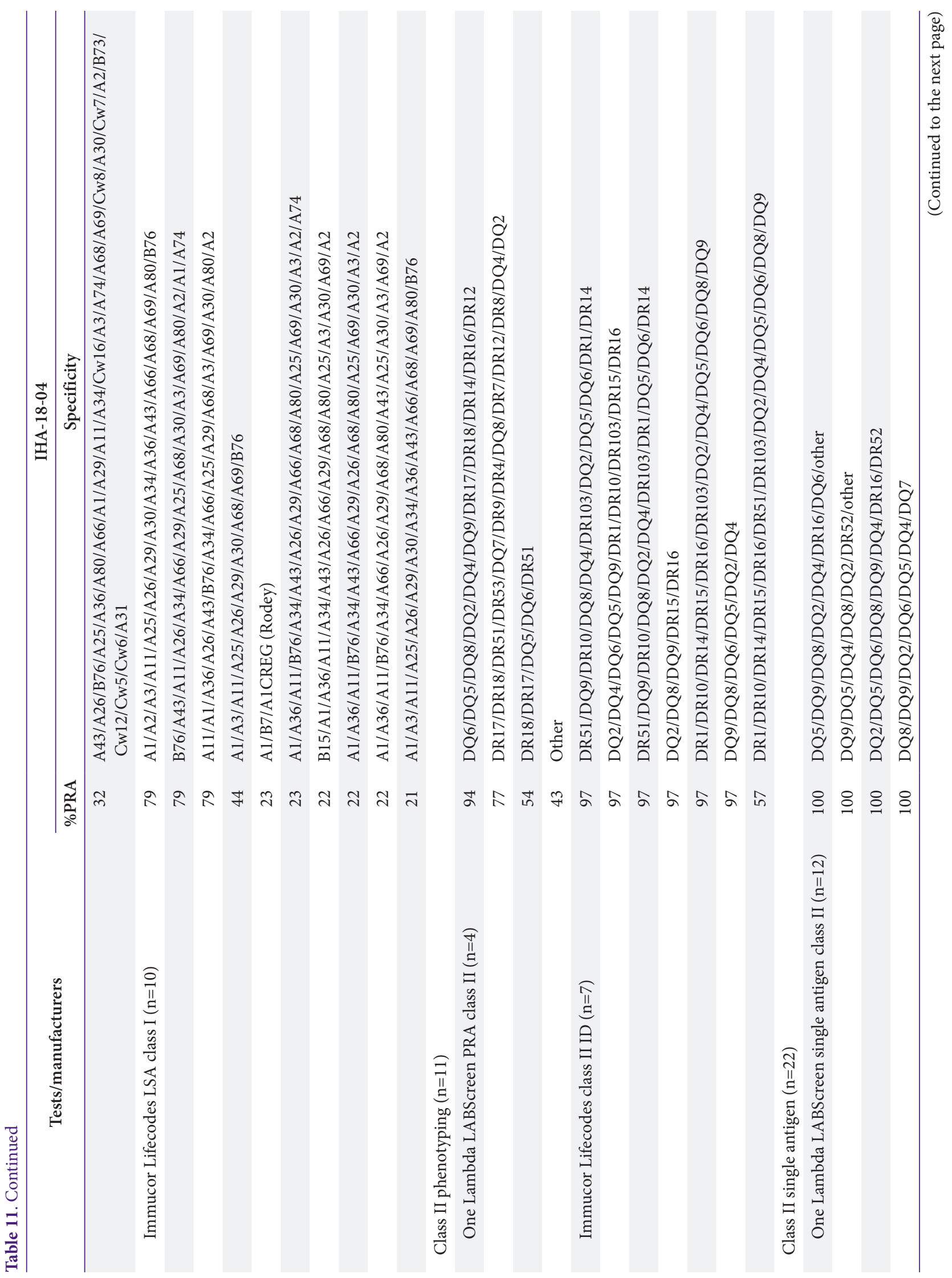


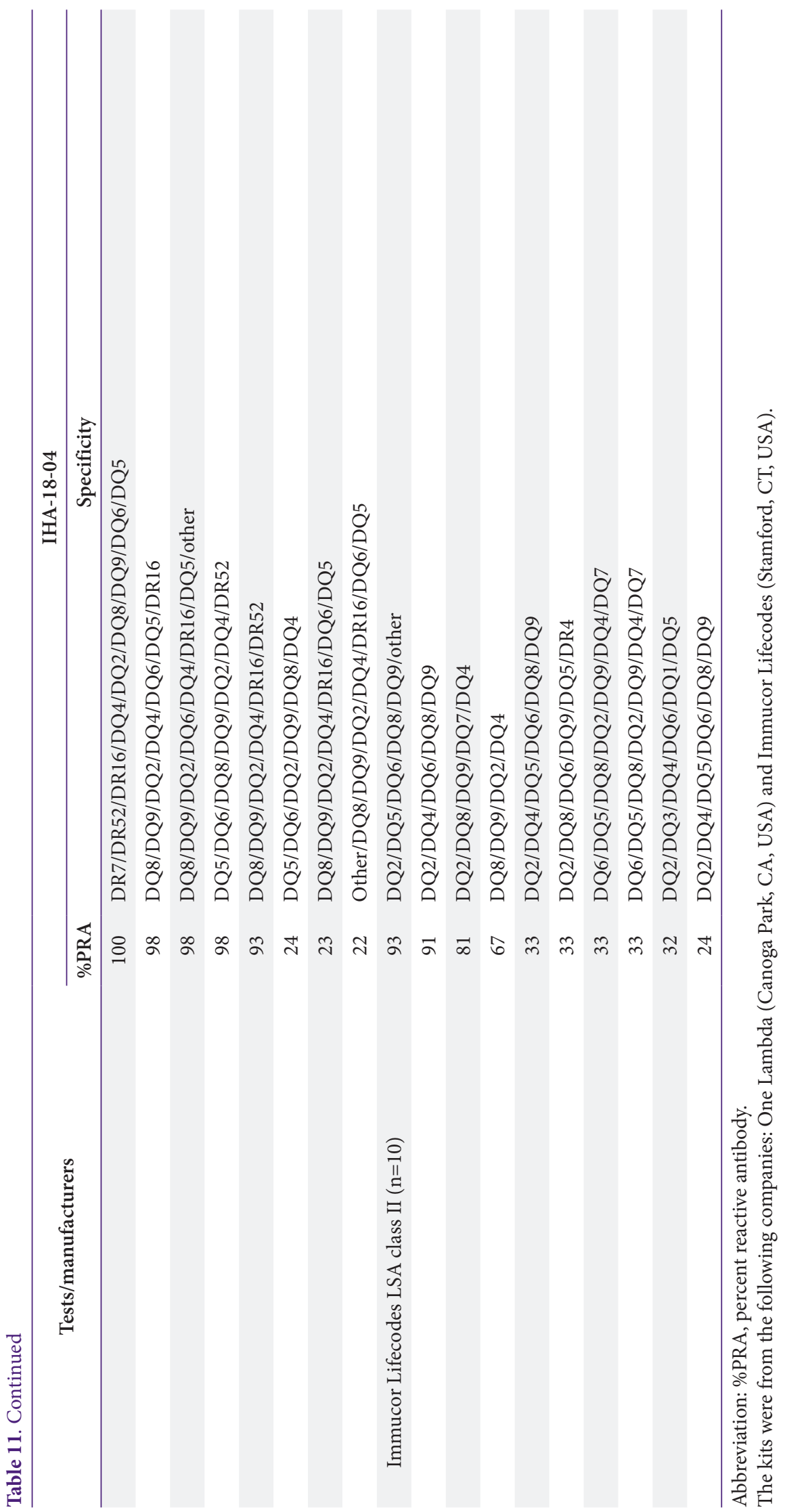


Eun-Suk Kang • Histocompatibility EQA

\section{감사의 글}

정도관리물질의 제조에 도움을 주신 박준우 선생님과 면역 검사실 선생님들 그리고 헌혈실 정혜경, 김혜미 간호사 및 정 미정 연구원에게 감사의 뜻을 전한다.

\section{REFERENCES}

1. Park MH. A questionnaire survey of HLA laboratories in Korea (1993). J Korean Soc Transplant 1993;7:245-8.

2. Park MH, Whang DH, Kim BC. Two-year study on the
HLA typing proficiency survey in Korea, 1996-1998. Korean J Clin Pathol 1999;19:714-22.

3. Marsh SG, Albert ED, Bodmer WF, Bontrop RE, Dupont B, Erlich HA, et al. Nomenclature for factors of the HLA system, 2010. Tissue Antigens 2010;75:291-455.

4. Lee KW, Park MH. New HLA nomenclature (2010) and its clinical application in Koreans. Korean J Lab Med 2010;30:203-17.

5. Yu S, Kang ES, Park MH. A questionnaire survey of HLA crossmatch tests in Korea (2015). Lab Med Online 2017;7:147-56. 